\title{
Should You Brand Your Family Business? Evidence from Research and Practice
}

\author{
Claudia Binz Astrachan (Lucerne University of Applied Sciences and Arts)
}

KEYWORDS: Sales, Marketing, Advertising, Marketing, Family Business.

Should you join the growing number of family businesses that proudly promote the fact that they are (and have been) family owned - for decades, some even for centuries? Or do you prioritize your family's privacy over leveraging your family's involvement in the business for the benefit of a distinct family business brand? Drawing on evidence from research and practice, this article provides some insights as to the circumstances under which it makes sense to brand a company as family-owned.

Nearly everybody in Germany immediately recognizes Claus Hipp, a $3^{\text {rd }}$ generation owner and a manufacturer of organic baby foods in Germany. Since the early 2000s he's been the face of the company's advertising. He's since appeared in thousands of TV spots on national TV, talking about HIPP being a pioneer in organic production. Each spot closes with his signature line: "For this, I vouch with my name" [Dafür stehe ich mit meinem Namen]. And HIPP is in good company: A growing number of family business owners are promoting the fact that they are (and have been) familyowned, for decades and some even for centuries. These family firms are banking on the possibility that their stakeholders appreciate the fact they are family-owned, and that the notion of family gives them a competitive edge over their competitors without any family involvement.

They do so for good reason: Prior research substantiates the intuitively appealing assumption that family firms have a superior reputation (e.g., Craig, Dibrell, and Davis, 2008; edelman.com). Several studies indicate that key stakeholders hold distinct associations with family-owned companies, viewing them as relatively more trustworthy, reliable, authentic, quality and customer-oriented than their non-family counterparts (e.g., Binz, Hair, Pieper, \& Baldauf, 2012).

However: Family business branding is hardly a magic bullet for family-owned companies. Evidence shows that context matters - a distinct family business brand may work well for some family firms, but not for others. If the notion of family adds no value to your stakeholders, or if your family shies away from the heightened scrutiny that comes with a family-based brand identity, branding yourself as family-owned can come at a cost.

\section{Signaling Family Involvement: Sender's and Receiver's Perspective}

What is a family business brand, or a family-based brand identity? Through a family business brand a company actively communicates the family's involvement in the business. Prior research has largely focused on the receiver side of the family business brand, investigating the distinct associations and expectations it creates in the minds of relevant stakeholders, such as customers or employees. These perceptions are shaped by the individual's general attitude towards the notion of "family" and the associations they hold with the idea of "family business." One customer might view family-owned companies as trustworthy and responsible, while another views them as outdated and resistant to change; one job-seeker might perceive them as loyal and long-term oriented, while another might be skeptical about a possible lack of transparency, or nepotistic tendencies.

Just like with any other messaging, however, we must consider not only the receiver, but also the sender's perspective on the family business brand. Here, we must think about whether (and how) the notion of family fits with our offering and existing messaging in other words, how does the family add value to our brand? What is more, we have to be sure that the family is willing to tolerate the heightened scrutiny that comes with becoming a representative of the business, and
Copyright @ 2021 The Authors. Entrepreneur \& Innovation Exchange is published at EIX.org. This is an open access article under the terms of the Creative Commons Attribution-NoDerivs License, which permits use and distribution in any medium, provided the original work is properly cited and no modifications or adaptations are made. View EIX.org Authorship Terms at https://eix.org/terms
FamilyBusiness 
part of the brand identity (Binz Astrachan \& Astrachan, 2015).

In sum, we must understand how our key stakeholders perceive family involvement, in both positive and negative ways. Various stakeholders might value the family business's strong customer or quality orientation, or they might see family involvement as a sign of nepotism and resistance to change. Only then can the family design a brand identity that leverages the positive, while mitigating some of the potentially negative perceptions. At the same time, family members must be ready to become ambassadors for that brand, and to embrace messaging that conveys how the family adds value to the company and to the stakeholders.

\section{How to Design a Compelling Family- Based Brand Identity}

Companies such as US conglomerate SC Johnson ("A family company"), Italian wine-maker dynasty Marchesi Antinori("26 Generations"), or Warburtons ("Family Bakers"), a family-owned bakery in the UK, all put family at the heart of their corporate brand. While they all highlight the owning family's involvement as a key element of their business success, they do so very differently. Antinori's narrative focuses on the expertise that the family has built, and passed down over 26 generations, while the Johnson family states that because they are family-owned, they can "do what's right for people and the planet" (scjohnson.com, May 2021). Warburtons state their dedication to quality and highlight that "they care because their name's on it" (warburtons.co.uk).

Family firms differ "in the extent to which the focal element of the branding strategy was the family, the [offering], or the organization" (Micelotta \& Raynard, 2011). While smaller and older family firms with less geographical reach have been found to be more likely to brand themselves as family-owned than larger, younger, and globally operating companies, the examples provided above show that a family-based brand identity can work for companies of any size. What matters is that the value the ownership group adds to the business is ultimately meaningful to the stakeholders -- that is, to the individuals who purchase their products and services, who apply for their job openings, or who agree to do business with them.

What's also interesting is that depending on the audience, different aspects of family involvement might resonate with them. William Grant \& Sons did extensive research before launching a family business brand for their Glenfiddich Whisky in 2013. Results from Asia showed that potential customers did not care much for family ownership, but that they really liked the notion of family management, and since William Grant \& Sons was, indeed, a family-run business, they decided to changed their tagline from the original "Family Owned" to "Family Run Since 1887." Interestingly, they only use the notion of family selectively in their corporate branding - they found that while some customers highly appreciate it, that it doesn't work so well for some of their other brands. William Grant \& Sons is an outstanding example of systematic family business branding: They took the time to identity how the notion of family resonated with different audiences and adopted a very differentiated branding strategy across their product portfolio.

Once we have identified what matters to our key stakeholders, we need to make sure that the family is aligned behind the brand messaging, and supports the move to using the family as a key element of the corporate of product/service brand. Not all family members may appreciate the heightened scrutiny that sometimes comes with a distinct family business branding strategy, and hearing and acting upon individual family members' concerns is crucial in establishing a firm foundation for your own family business brand.

\section{Three Keys to Successful Family Business Branding Know Your Audience}

A distinct family business brand can positively impact key constituencies such as customers or employees. However, it can also lend to negative associations such as smallness and resistance to change, or nepotism and lack of transparency that might disenfranchise others (i.e., lenders, suppliers, buyers). Before anything, you must first therefore determine how your key constituencies feel about the notion of family. Once you know that family involvement is generally considered positive, identify which expressions of family involvement they feel favorable about (e.g., family ownership, family involvement in management, experience built over generations, strong local/regional/national roots, financial or strategic independence), and which expressions might trigger 
negative associations. These perceptions might differ not just within, but across cultures and stakeholder groups.

\section{Identify how the Family Can Add Value}

Once you have identified the ways in which the notion of family can add value to your brand, identify which ones feel most authentic and natural to your family. For example, you may be particularly concerned about quality because your product is part of your identity; your strong customer orientation is rooted in the family's understanding of customers being part of the extended family. Ideally, these expressions align closely with your family's identity -- your core values and objectives. Figure 1 below visualizes the sequential process of designing a family business brand, starting with the identity of the ownership group: The family identity (how you see yourself) is the core, the family firm brand image (how you want others - your stakeholders - to see you) is the middle layer, and the family firm brand reputation (how others - your stakeholders - see you) represents the outermost layer.

- In a first step, you need not only clarity, but also alignment around your family and your business identity: Who are you as a family, as an organization? What are your central values and objectives, and are these widely shared in the family and the business? If we lack a strong identity foundation, it becomes much harder to develop - and implement, let alone live! - a strong family firm brand.

- Once we have agreement on our identity foundation, we can move on to our family firm brand image, which focuses on how we would like others to see us. Here, we must think about things such as our family promise - what does our family bring to the table that helps us differentiate our offering in the marketplace? Warburtons, the bakery mentioned earlier, is run by three cousins, and they take quality control very seriously - to the point where every month, one of the three cousins pays a quality control visit one of their plants. They live their core value of quality orientation by personally assuring that their operations remain up to their standards.

- Lastly, we must keep track of how our stakeholders actually perceive us - our reputation - which is largely driven by how consistent our actions are with the way in which we portray ourselves; in other words, it pertains to the question of "do we live our values?"

Figure 1: Family Business Brand Identity, Image, and Reputation Matrix (Binz Astrachan et al., 2018)

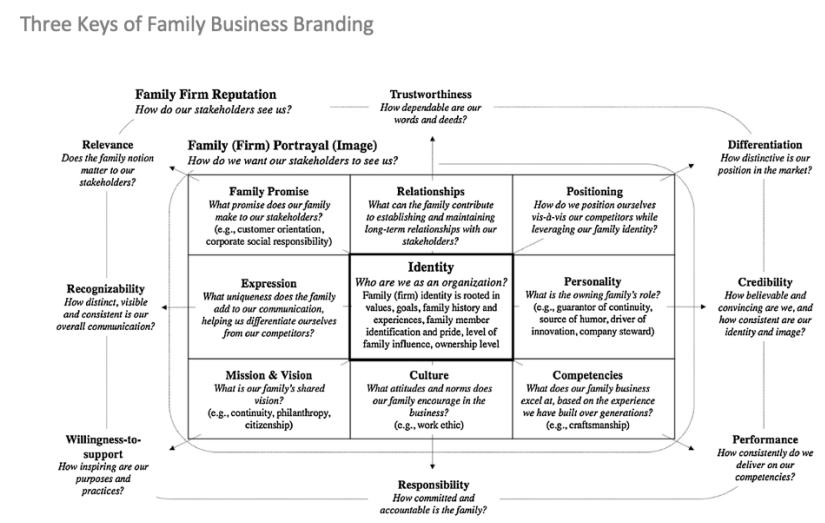

\section{Rally the Family and Bring Your Values to Life}

Putting the family at the center of one's brand identity is not for everyone. A distinct family business brand depends on the family's willingness to have a public profile, as it increases the visibility of and scrutiny on the owning family. A family business brand requires family members to consistently embody the brand promise - a responsibility all family members need to be in agreement with. Any kind of misconduct on the part of family members inside as well as outside the business can threaten the reputation of both the family and the firm, which could lead to damage for the family business brand (particularly if the family and business reaction are not managed in an authentic manner consistent with the family's values and brand message). The family therefore needs to ensure that mechanisms are in place that allow them to respond quickly and adequately to any situations caused by escalated family conflicts or wayward behavior on behalf of family members that may be publicized. Lastly, increased visibility can also come with heightened risk for family members. Many entrepreneurial families around the world, particularly in countries that have significant political instability and corruption in law enforcement, have experienced traumatic incidents involving blackmailing or even abduction.

It's clear that a family business brand rises and falls with the brand representatives' ability to live the values they 
promote. When family members exemplify these values through their own behavior and by the examples that they set, it breathes life into the values that define the company and the family. Making values visible and tangible ensures that employees and other stakeholders are reminded regularly of what the company stands for.

\section{Final Thoughts}

Family-owned companies are in a unique position to leverage their family and company history, the outstanding contributions of family members that shaped the family business over decades, or their dedication to the long-term and the well-being of their many constituencies by means of a distinct family business brand. Given how a family business brand can push family members into the spotlight, however, it is not a decision that should be taken lightly - and it is most certainly a process that requires the engagement of all family members who will be affected by it. On the other hand, a family-based brand identity can foster family members' family identification with the business, which can be particularly meaningful for family firms with larger, geographically dispersed and growing ownership groups.

You can portray your family involvement, and the uniqueness of your family, in many ways. And if you do it well, you might become a Twitter sensation just like Mel's Lone Star Lanes in Texas, a bowling alley whose sign reads:

"Family Owned. Shut Up. No, You Shut Up!"

\section{References}

Binz Astrachan, C., Botero, I., Astrachan, J. H., \& Prügl, R. (2018). Branding the family firm: A review, integrative framework proposal, and research agenda. Journal of Family Business Strategy, 9(1), 3-15.

Binz Astrachan, C., \& Astrachan, J. H. (2015). Family business branding: Leveraging stakeholder trust. London: Institute for Family Business Retrieved from https://blog.hslu.ch/familienunternehmen/ files/2016/09/IFBRF-Branding-Report-Final-WebVersion-1.pdf

Binz, C., Hair Jr, J. F., Pieper, T. M., \& Baldauf, A. (2013). Exploring the effect of distinct family firm reputation on consumers' preferences. Journal of Family Business Strategy, 4(1), 3-11.
Craig, J. B., Dibrell, C., \& Davis, P. S. (2008). Leveraging family-based brand identity to enhance firm competitiveness and performance in family businesses. Journal of Small Business Management, 46(3), 351-371.

Micelotta, E. R., \& Raynard, M. (2011). Concealing or revealing the family? Corporate brand identity strategies in family firms. Family Business Review, 24(3), 197-216. 